\title{
Treatment of Serious Occlusal Instability Associated with Temporomandibular Disorders (TMDs) Through Implant and Dynamic Occlusal Schemes Rehabilitation. A Case Report
}

\author{
Rehabilitación Mediante Implantes y Restablecimiento de Esquemas Oclusales Dinámicos en \\ Inestabilidad Oclusal Severa Asociada a Trastornos Temporomandibulares. Reporte de un Caso
}

Gabriela Molina'; Alejandro Signorio'; Roberto Hernandez'; Gilberto Salazar' \& César Coronado Gallardo²

MOLINA, G.; SIGNORIO, A.; HERNANDEZ, R.; SALAZAR, G. \& CORONADO, G. C. Treatment of serious occlusal instability associated with temporomandibular disorders (TMDs) through implant and dynamic occlusal schemes rehabilitation. A Case Report. Int. J. Odontostomat., 15(2):479-483, 2021.

ABSTRACT: A case report of 35 years old male patient, partially edentulous with occlusal instability, Disc Displacement with Reduction (DDWR), Local Muscle Soreness (LMS) and Alteration of vertical dimension is presented. Rehabilitation was planned to achieve predictability of long-term treatment, providing static and dynamic occlusal stability. A therapeutic occlusion with premature contact in the right premolar sector was planned. Implants and cemented/screwed crowns were used to obtain contacts in the molar area. The restoration of dynamic occlusal schemes was made by direct adhesive technique in the anterior sector and Curve of Spee (COS) compensation with temporary anchoring for molar inclusion was used. Patient presents objective and subjective improvements associated with the treatment performed. Temporomandibular disorder is stabilized and controlled by a specialist.

KEY WORDS: Occlusal instability, temporomandibular disorder, osseointegrated implants.

\section{INTRODUCTION}

Occlusal Vertical Dimension (OVD) can be altered in patients with posterior and/or anterior tooth loss (Fabbri et al., 2018). Tooth loss can destabilize static occlusion (maximum intercuspation) and dynamic occlusion. This could be a trigger erosive occlusal alterations and affects the balance of system according to the patient's ability to adapt (Rues et al., 2011).

Cephalometric analysis is an additional option to clinical tools as a method for Vertical Dimension evaluation. Ricketts analysis is a vertical measurement of the lower third. This analysis shows the skeletal relationship between both jaws, being a measure of proportionality (angular) decisive in the examination of the vertical dimension. Severe skeletal patterns have increase values (Carrera Vidal et al., 2010).
Mutually protected occlusion, laterotrusive guides with canines active participation (Miralles, 2016), protrusives guides dependent on anterior teeth and MIP posterior teeth contact (Qi et al., 2018), are a protective stomatognathic system stability factor. The principal treatment objective is restored this parameters.

Osseointegrated implants use has allowed restore the functionality of edentulous spaces, restoring an aesthetically similar as a natural tooth but biomechanically different than it (Robinson et al., 2019). The forces acting on tooth determinate their long-term maintenance and a predictable treatment.

Temporomandibular disorders (TDMs) could be associated with mandibular musculature hyperactivity

\footnotetext{
${ }_{1}^{1}$ Postítulo de Especialización Odontológica en Implantología, Facultad de Odontología, Universidad San Sebastián, Bellavista 7, Santiago 8420524, Chile.

${ }^{2}$ Instituto de Ciencias Biomédicas, Facultad de Ciencias de la Salud, Universidad Autónoma de Chile, Santiago, Chile.
} 
MOLINA, G.; SIGNORIO, A.; HERNANDEZ, R.; SALAZAR, G. \& CORONADO, G. C. Treatment of serious occlusal instability associated with temporomandibular disorders (TMDs) through implant and dynamic occlusal schemes rehabilitation. A Case Report. Int. J. Odontostomat., 15(2):479-483, 2021.

(Manfredini \& Lobbezoo, 2010), generatingheavy occlusal contacts between upper and lower arch, this could lead to muscular and occlusal alterations (Melo et al., 2019), consequently the muscle hyperfunction should be controlled previously the treatment.

This case report will show the integral management of a patient with TMD, severe occlusal instability, tooth loss and generalized attrition teeth, by using posterior implants, temporary anchorage for left Curve of the Spee ( COS) compensation and direct adhesive technique in anterior sector.

\section{CASE DESCRIPTION}

A 35 years old, male patient, without significant medical history, was attended in the Dental Faculty of San Sebastian University, because he presented missing posterior teeth. In extraoral examination the preoperative VAS (Visual Analogue Scale) pain score 3 in the Temporomandibular Joints (TMJ) area and 2 in the masseter muscles on both sides was detected. A clicking sound in the right TMJ is detected at 26 millimeters mandibular opening with deviation to the same side, recovering midline at the end of the opening. A Míchigan splint was made as emergency phase during four months.

Intraoral Examination results detected a partially edentulous patient, Kennedy class III, modification I in the upper arch and Kennedy class III in the lower arch. The patient presented missing of teeth $1.6,2.4,2.5,2.6,4.6,1.3$. The extrusion on tooth 3.6 altered the left Curve of the Spee (COS), also according to the Smith and Knight tooth wear index (TWI), he had 1, 2 and 3 grades. Panoramic radiograph showed a moderate horizontal bone loss in both jaws, dental agenesis of tooth 1.3 and Normal maxillary sinus were detected.

Diagnostic models were mounted in Whipmix 2240 articulator to obtain a Centric Relation (CR) by an anterior deprogrammer and the chin-point technique, afterward using the premature contact of teeth 1.5 and 4.5 a wax up model were made to radiographic previous guide and surgical guide. Lower facial height by Ricketts lateral cephalometric analysis was $53^{\circ}$. The treatment started with the etiological phase by supragingival and subgingival scaling. Afterwards the corrective phase was started and the dynamics occlusal schemes were restored with adhesive direct technique in the anterior sector. Bilateral anterior group functions are established modifying anatomy of 1.4 tooth from premolar to canine.

The surgical phase started with a lateral sinus lift surgery in site 2.6 and Straumann $®$ Bone Level Tapered Implant ( $\varnothing 4.1-10 \mathrm{~mm})$ was positioned. Then two implants Straumann ${ }^{\circledR}$ Bone Level Tapered Implant $(\varnothing$ 3.3.-10mm) in site 2.4 and 2.5 , one implant Straumann ${ }^{\circledR}$ Bone Level Taperedlmplant $(\varnothing$ 4.1.-10mm) in site 4.6 and one implant Straumann ${ }^{\circledR}$ Bone Level Tapered Implant ( $\varnothing$ 4.8.-8mm) in site 1.6 were placed. Implants were left submerged and after 3 months the abutments connection was made, also a connective tissue graft from the palate was place from improve gingival biotype next to the area of implants 2.4, 2.5 and 2.6. Then five implants were provisionalizated over temporary titanium abutments.

The intrusion of tooth 3.6 by temporary anchoring device using two Neodent $₫$ Ancoragem orthodontic miniimplants $(\varnothing 1.6-7 \mathrm{~mm})$ in the interdental area was performed to get compensation of the left Curve of the Spee (COS). A cemented bracket was used in center of the clinical crown using a long elastomeric chain with 20 $\mathrm{g}$ force to obtain $0.75 \mathrm{~mm}$ intrusion in a month, until getting approximately $2 \mathrm{~mm}$ of intrusion in 2 months. A heavy occlusal contact in the supporting cusp on temporary crown 2.6 was performed.

For the implant-supported rehabilitation phase, individual biomechanics were used to optimized stress distribution. Finally, Straumann ${ }^{\circledR}$ Variobase ${ }^{\mathrm{TM}}$ abutments were selected for cemented screwed rehabilitation with zirconia crowns and digital workflow. the initial characteristics and the results of the case treatment are shown in Figure 1.

\section{DISCUSSION}

Rehabilitation with dental implants requires careful surgical / prosthetic planning, the occlusal loads that the implants receive is decisive in the long term, especially in situations of occlusal overload. Sadowsky (2019) reports that about one third of patients with bruxism can generate forces that cause microfractures in the bone, resulting in bone loss and probable later implant failure, and this decrease can be associated with plaque accumulation (Chambrone et al., 2010). Chitumalla et al. (2018) report that excessive occlusal overload caused in bruxism patients is the main cause of failure, such as implant fracture, screw loosening, screw fracture and porcelain fracture. 


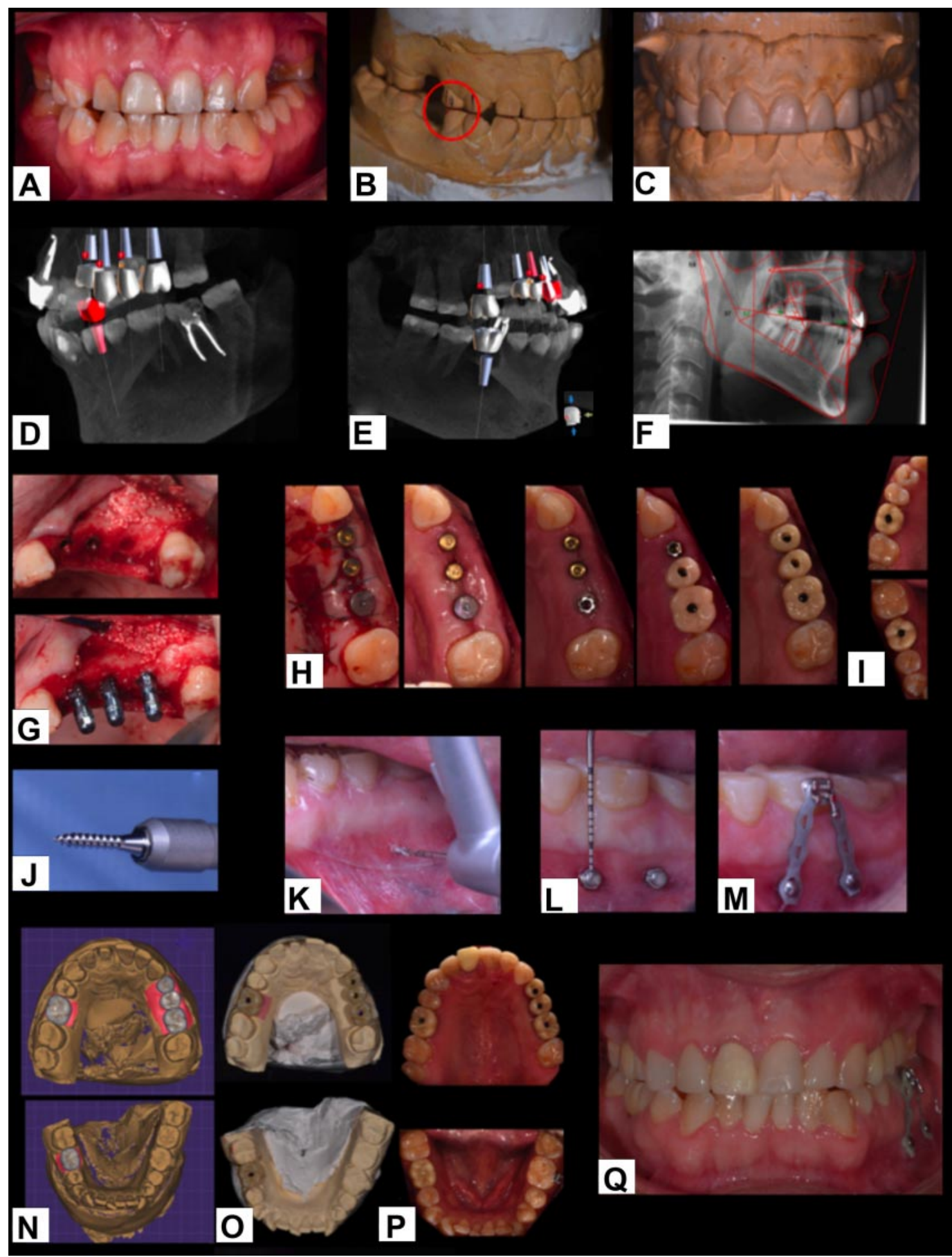

Fig. 1. A) Intercuspal Position (ICP) B) premature contact: 1.5-4.5 sup erior vestibular cusp and inner slope/ inferior vestibular cusp and inner slope C) diagnostic wax-up D) 2.4,2.5,2.6 Implant planning E) 1.6,4.6 implant planning F) ricketts lower facial height $G$ ) lateral sinus lift surgery in site 2.6 , implants were placed in site 2.4, 2.5 and 2.6. H) temporary crowns on the left side I) temporary crowns on the right side J) Neodent Ancoragem ${ }^{\circledR} 1.6 \times 7 \mathrm{~mm}$ (transmucosal height : $1 \mathrm{~mm}$ ) I. first drill, K). two mini implants were placed. L) bracket and continuous chain $\mathrm{M}$ ) digital planning for rehabilitation $\mathrm{N}$ ) zirconia monolithic crowns on working model $\mathrm{O}$ ) zirconia monolithic crowns on variobase abutments in the mouth P) final intercuspal position (ICP). 
MOLINA, G.; SIGNORIO, A.; HERNANDEZ, R.; SALAZAR, G. \& CORONADO, G. C. Treatment of serious occlusal instability associated with temporomandibular disorders (TMDs) through implant and dynamic occlusal schemes rehabilitation. A Case Report. Int. J. Odontostomat., 15(2):479-483, 2021.

For the loss of three posterior teeth, there is the possibility of using two or three implants, however, this will be conditioned by the quality and quantity of bone.No Epidemiologic Catchment Area (ECA) study or other prospective studies that directly compared the number of implants under partially edentulous maxillary conditions were found. Sato et al. (2012), based on the classic conceptual figure of Rangert, reported that for rehabilitation cases with multiple implants in partially edentulous posterior maxillae and where it is required to return the posterior occlusal table, if space is available, the placement of three implants, being biomechanically more favorable than two implants and a plural fixed prosthesis in the distribution of stress.

Koyano \& Esaki (2015) reported that in cantileverassisted multiple implant restorations, changes in the level of the marginal bone, loosening of prosthetic screws, changes in occlusal contacts and vertical dimension were detected. Cantilever loading should be avoided because it generates unfavorable tensile forces and biomechanical complications.

Individual restorations in the posterior maxillary sector were considered for load distribution in individual crowns and restorative rationality. There are recommendations for splinting crowns in patients with occlusal overload, however, there is no adequate clinical or histological evidence that splinting implant crowns improves long-term performance (Sadowski, 2019). During the corrective phase, correction to dynamic occlusal schemes, leveling of the left Curve of the Spee (COS) with temporary anchorage for molar inclusion and patient adaptation during the provisionalization were performed to recover posterior occlusal contacts and a mutually protected occlusion.

The selection of an occlusal scheme for dentate or partially edentulous patients requiring fixed implant or conventional rehabilitations may vary depending on the patient's preconditions. The occlusal scheme is challenged by missing teeth, uneven occlusal planes, skeletal malocclusions, severely worn dentitions, advanced periodontal disease and temporomandibular disorders (TMD) (Wiens \& Priebe, 2014).

The challenge should be to create a therapeutic occlusion that provides a static and dynamic occlusal stability, requiring a repeatable closure in central relation $(\mathrm{CR})$ in an appropriate Occlusal Vertical Dimension (OVD) with joint and neuromuscular stability, providing dynamic occlusal schemes that work as protective factor of the stomatognathic system in a mutually protected occlusion (Racich, 2018). Consideration should be shown to the adaptive dynamic and continuous physiological nature in which a patient's occlusion may change before, during and after treatment.

Classical approaches suggested that an increased Occlusal Vertical Dimension (OVD) resulted in muscle tension, muscle hyperactivity and a predisposition to muscle pain (Monteith, 1984).

In contrast, another study of contemporary classical approach about electromyographic (EMG) activity, raised the opposite, Manns et al. (1981) showed that EMG activity at rest of the masseter muscle was minimal in an intermediate range of mouth opening that varied between 10 and $16 \mathrm{~mm}$, depending on the muscle studied.

Meanwhile, Abduo (2012) reports that the stomatognathic system has the ability to adapt rapidly to moderate changes in OVD $(<5 \mathrm{~mm})$.

If there are therapeutic prosthetic needs to increase the Occlusal Vertical Dimension (OVD) to provide functionality to the designed therapeutic occlusion, minimal changes should be incorporated, maintaining orthopedic stability during the change, adapting the patient with temporary prototypes and/or interocclusal devices.

The patient should be observed for an adequate period of time to ensure an adaptation before final rehabilitation. Permanent occlusal changes should only be attempted after the patient has demonstrated adaptability of the vertical dimension in the designed therapeutic occlusion (Moreno-Hay \& Okeson, 2015).

In the present case, no occlusal stability was observed. When evaluating the difference between Maximum intercuspation position (MIP) and central relation (CR) after deprogramming, it was decided to take as a reference the premature contact revealed after the deprogramming process to establish the position in which the patient would be rehabilitated, and from there to recover static and dynamic occlusal schemes that allow adequate function after the patient adapts to the designed therapeutic occlusion.

Molar overeruption in patients who had lost the antagonist tooth is frequent and can make implantassisted rehabilitation difficult by reducing adequate prosthetic space for predictable rehabilitation (Sudhindra et al., 2010). 
Ayadi et al. (2018) described molar intrusion as a movement whose technique leads the tooth vertically towards its bone base. Mini implants can be used to perform the intrusion of a single tooth to a group, considering them as a less invasive alternative to a restorative approach requiring endodontic treatment, posts and fixed prostheses to level the occlusal plane, with the disadvantage that it can increase restoration times, however, the biological cost associated with a conventional prosthetic technique is decisive when choosing this therapeutic option.

In this case report, a cemented bracket is used in the centre of the clinical crown and 20 grams of force are applied with a long chain, during 2 months, to insert $2 \mathrm{~mm}$ the tooth 3.6 and obtain an adequate prosthetic space to rehabilitate the antagonist implant. The Left Curve of the Spee ( COS) is compacted to obtain a dynamic occlusal scheme created.

MOLINA, G.; SIGNORIO, A.; HERNANDEZ, R.; SALAZAR, G. \& CORONADO, G. C. Rehabilitación mediante implantes y restablecimiento de esquemas oclusales dinámicos en inestabilidad oclusal severa asociada a trastornos temporomandibulares. Reporte de un Caso. Int. J. Odontostomat., 15(2):479-483, 2021.

RESUMEN: Se presenta el caso clínico de un paciente masculino de 35 años, parcialmente desdentado con inestabilidad oclusal, Desplazamiento Discal con Reducción (DDWR), Dolor Muscular Local (LMS) y Alteración de la dimensión vertical. La rehabilitación se planificó para lograr la previsibilidad del tratamiento a largo plazo, proporcionando estabilidad oclusal estática y dinámica. Se planificó una oclusión terapéutica con contacto prematuro en el sector premolar derecho. Se utilizaron implantes y coronas cementadas / atornilladas para obtener contactos en la zona de los molares. La restauración de esquemas oclusales dinámicos se realizó mediante técnica de adhesivo directo en el sector anterior y se utilizó compensación de Curva de Spee (COS) con anclaje temporal para inclusión molar. El paciente presenta mejoras objetivas y subjetivas asociadas al tratamiento realizado. El trastorno temporomandibular es estabilizado y controlado por un especialista.

PALABRAS CLAVE: inestabilidad oclusal, trastorno temporomandibular, implantes osteointegrados.

\section{REFERENCES}

Abduo, J. Safety of increasing vertical dimension of occlusion: a systematic review. Quintessence Int., 43:369-80, 2012.

Ayadi, I.; Dallel, I.; Ben Rejeb, S.; Tobji, S.; Ben Amor, F. \& Ben Amor, A. Ingression orthodontique sur mini-vis d'ancrage. Orthod. Fr., 89(4):397410, 2018.
Carrera Vidal, C.; Larrucea Verdugo, C. \& Galaz Valdés, C. Detection of Increases of Vertical Occlusal Dimension by Ricketts Cephalometric Analysis. Rev. Clin. Periodoncia Implantol. Rehabil. Oral, 3(2):79-85, 2010

Chambrone, L.; Chambrone, L. A. \& Lima, L. A. Effects of occlusal overload on peri-implant tissue health: a systematic review of animal-model studies. J. Periodontol., 81(10):1367-78, 2010.

Chitumalla, R.; Halini Kumari, K. V.; Mohapatra, A.; Parihar, A. S.; Anand, K. S. \& Katragadda, P. Assessment of survival rate of dental implants in patients with bruxism: a 5-year retrospective study. Contemp. Clin. Dent., 9(Suppl. 2):S278-S282, 2018.

Fabbri, G.; Sorrentino, R.; Cannistraro, G.; Mintrone, F.; Bacherini, L.; Turrini, R.; Bombardelli, T.; Nieri, M. \& Fradeani, M. Increasing the vertical dimension of occlusion: a multicenter retrospective clinical comparative study on 100 patients with fixed tooth-supported, mixed, and implantsupported full-arch rehabilitations. Int. J. Periodontics Restorative Dent., 38(3):323-35, 2018.

Koyano, K. \& Esaki, D. Occlusion on oral implants: current clinical guidelines. J. Oral Rehabil., 42:153-61, 2015.

Manfredini D. \& Lobbezoo, F. Relationship between bruxism and temporomandibular disorders: a systematic review of literature from 1998 to 2008. Oral Surg. Oral Med. Oral Pathol. Oral Radiol. Endod., 109(6):e26-50, 2010.

Manns, A.; Miralles, R. \& Guerrero, F. The changes in electrical activity of the postural muscles of the mandible upon varying the vertical dimension. J. Prosthet. Dent., 45:438-45, 1981.

Melo, G.; Duarte, J.; Pauletto, P.; Porporatti, A. L.; Stuginski-Barbosa, J.; Winocur, E.; Flores-Mir, C. \& De Luca Canto, G. Bruxism: An umbrella review of systematic reviews. J. Oral Rehabil., 46(7):666-90, 2019.

Miralles, R. Canine-guide occlusion and group function occlusion are equally acceptable when restoring the dentition. J. Evid. Based Dent. Pract., 16(1):41-3, 2016.

Monteith, B. The role of the free-way space in the generation of muscle pain among denture-wearers. J. Oral Rehabil., 11:483-98, 1984.

Moreno-Hay, I. \& Okeson, J. P. Does altering the occlusal vertical dimension produce temporomandibular disorders? A literature review. J. Oral Rehabil., 42(11):875-82, 2015.

Qi, K.; Xu, Y.; Hou, Y. \& Wang, M. Q. Comparison of posterior occlusion between patients with anterior open bite and scissor deep bite. J. Int. Med. Res., 46(6):2284-91, 2018.

Racich, M. J. Occlusion, temporomandibular disorders, and orofacial pain: An evidence-based overview and update with recommendations $\mathrm{J}$. Prosthet. Dent., 120(5):678-85, 2018.

Robinson, D.; Aguilar, L.; Gatti, A.; Abduo, J.; Lee, P. V. S. \& Ackland, D. Load response of the natural tooth and dental implant: A comparative biomechanics study. J. Adv. Prosthodont., 11:169-78, 2019.

Rues, S.; Lenz, J.; Türp, J. C.; Schweizerhof, K. \& Hans, J. Schindler. Muscle and joint forces under variable equilibrium states of the mandible. Clin. Oral Investig., 15:737-47, 2011.

Sadowsky, S. J. Occlusal overload with dental implants: a review. Int. J. Implant Dent., 5(1):29, 2019.

Sato, Y.; Uchida, K.; Okuyama, T. \& Kitagawa, N. Verification of the influence of the arrangement of implants on the load distribution (a well-known figure by Rangert). J. Oral Rehabil., 39:446-9, 2012.

Sudhindra, M.; Shivankumar, N. O.; Arvind, M.; Ramesh, C. \& Baswakymar, M. Management of supraerupted posterior teeth: a review. Int. J. Dent. Clin., 2:27-30, 2010.

Wiens, J. P., \& Priebe, J. W. Occlusal stability. Dent. Clin. North Am., 58(1):19-43, 2014.

Corresponding author:

César Coronado Gallardo

Centro de Integrado de Salud

Universidad Autónoma de Chile

El Llano Subercaseaux \# 2801

Santiago - CHILE

E-mail: cesar.coronado@uautonoma.cl 